\title{
Katarzyna Dziewanowska
}

\author{
Uniwersytet Warszawski \\ Wydział Zarządzania \\ e-mail: kdziewanowska@wz.uw.edu.pl

\section{Dimensions of brand commitment - case of higher education}

Codes JEL: M30, M31, I23

Keywords: brand community, commitment, higher education

Summary. The paper consists of two parts and focuses on brand community commitment in higher education, its dimensions and relationship with students' loyalty. The first part presents the literature review on brand community and commitment. In the second part of the paper, results of quantitative study are presented and discussed. The study objectives include the verification of three-dimensional brand community commitment model in higher education (consisting of affective, continuance and normative components) and the relationship between its dimensions and the student loyalty towards a university.

\section{Introduction}

Higher education represents a sector of professional services, where relationships between the provider and the consumer are of particular importance. Building brand communities around universities is one of the activities that may allow higher education institutions to achieve the competitive advantage and organizational goals (e.g. loyalty, donations, image).

The aim of this paper is to present brand communities in general and then in the context of higher education, as well as to analyze brand community commitment and its relationship with the student loyalty towards the university. First, the literature review is presented, then the results of a quantitative study (survey) are discussed. The results of the study prove the three-dimensional construct of brand 
community commitment in higher education and explore correlations of its dimensions with students' loyalty. In the final part of the paper conclusions and practical implications are briefly discussed.

\section{Brand communities in higher education}

Enduring consumer groups practicing common consumption behavior have been in the spotlight of research interests for over four decades. They have been labeled as ,consumption communities” (Boorstin, 1973), „subcultures of consumption” (Schouten, McAlexander, 1995), ,neo-tribes” (Cova, 1997), „life-mode communities” (Firat, Dholakia, 1998), ,cultures of consumption” (Kozinets, 2001), „brand communities” (Muniz, O'Guinn, 2001; McAlexander, Schouten, Koenig, 2002), and „brand cults” (Belk, Tumbat, 2005).

The most commonly used definition of brand community states that it is „a specialized, non-geographically bound community, based on a structured set of social relationships among admirers of a brand" (Muniz, O'Guinn, 2001, p. 412). Although various other definitions exist, the literature review reveals that they all share at least three core components: consciousness of a kind, presence of shared rituals and traditions and a sense of moral responsibility. In contrast to other types of consumer groups, brand communities are not marginal subcultures and they tend to embrace the surrounding culture rather than reject it. Brand communities are characterized by relative stability and rather high level of commitment of their participants. Theoretically, they may form around any brand, but it is more likely that they form around brands that have a rich history, strong image and fierce competitors (Muniz, O'Guinn, 2001). Since brand communities are versatile and dynamic phenomena, they can differ on several dimensions, including social context, temporality, geographic concentration and basis of identification of their members (McAlexander, Schouten, Koenig, 2002).

Brand communities exist in various contexts - there is no doubt that such communities of committed and involved consumers are also present in the higher education sector. McAlexander, Koenig and Schouten (2006) presented and tested a model reflecting various relationships existing within university brand communities. They also emphasized the importance of brand community integration and suggested that the biggest value results from looking at these relationships collectively, not separately. The relationships (McAlexander, Schouten, Koenig, 2002) include:

a) the customer-product relationship (product understood as education or study major);

b) the consumer-brand relationship (students' attitudes and attachment to the university brand);

c) the customer-institution relationship (relations existing between students and university representatives such as lecturers, administrative staff); 
d) the customer-customer relationship (relations and interactions among students themselves).

Empirical research on brand communities in higher education is not limited to the verification of the above model. Other studies focused on relationship of the brand community integration with loyalty-related behaviors among students and alumni (such as future donations, purchase of university logo merchandise, positive recommendation) (McAlexander, Koenig, Schouten, 2006; McAlexander, Koenig, 2010; Martin, Moriuchi, Smith, Moeder, Nichols, 2015; Dziewanowska, 2016).

\section{Commitment in brand communities and its consequences}

Commitment is defined as ,a force that binds an individual to a course of action of relevance to one or more targets" (Meyer, Herscovitch, 2001, p. 301), thus community commitment is understood as the psychological bond existing between the community and its members (Zhang, Zhou, Su, Zhou, 2013). This construct is of multidimensional nature and it consists of affective, continuance and normative dimensions (Allen, Meyer, 1990) reflecting bonds based on the individual's:

- affect (emotional ties, attachment to, identification with and involvement in the community),

- need (perceived sunk costs and the member's belief that their involvement in the community provides them with benefits not available elsewhere),

- perceived obligation to remain in the community and support other members.

Previous studies on the brand community commitment prove that it plays a critical role in the relationship marketing (Morgan, Hunt, 1994) and has positive impact on brand loyalty (Algesheimer, Dholakia, Herrmann, 2005; Jang, Olfman, Ko, Koh, Kim, 2008) defined as inclination to positive word-of-mouth and repurchase intention.

\section{Research methodology}

The research problem in this study is twofold: first, the dimensions of brand community commitment in higher education are investigated, then the relationship between brand commitment dimensions and students' loyalty towards the university are analyzed. Based on the literature review it is assumed that brand community commitment consists of three dimensions: affective, continuance and normative (Allen, Meyer, 1990).

The following research hypotheses were proposed:

H1. Brand community commitment in higher education consists of three dimensions: affective, normative and continuance. 
H2. There are differences in the level of student commitment among higher education institutions.

H3. There are differences in the level of student commitment between males and females.

H4. There is a positive correlation between dimensions of the brand community commitment and students loyalty towards university.

The research method used in the study is a survey. The questionnaire consisted of two parts: in the first part questions about brand community commitment were asked (with a 5-point Likert scale anchored at $1-$,,strongly disagree" and 5 - ,strongly agree"), the second part consisted of questions about the sample characteristics. The questionnaire was distributed in paper version among students from four faculties at three Polish public universities and data was collected in March-April 2016. The sample consisted of 536 respondents selected with quota sampling technique so that they represented faculties of various profiles (humanities, social science, economic and technical). Detailed characteristics of the sample are presented in table 1.

Table 1

Sample characteristics

\begin{tabular}{|l|c|c|c|c|}
\hline University & $\begin{array}{c}\text { Warsaw University } \\
\text { of Life Sciences }\end{array}$ & $\begin{array}{c}\text { Warsaw School } \\
\text { of Technology }\end{array}$ & \multicolumn{2}{|c|}{ University of Warsaw } \\
\hline Faculty & Economics & $\begin{array}{c}\text { Civil } \\
\text { Engineering }\end{array}$ & Management & $\begin{array}{c}\text { Law and } \\
\text { Administration }\end{array}$ \\
\hline Female & 85 & 53 & 127 & 85 \\
Male & 33 & 51 & 51 & 50 \\
\hline Year 1 & 3 & 13 & 3 & 1 \\
Year 2 & 35 & 66 & 95 & 82 \\
Year 3 & 36 & 17 & 0 & 21 \\
Year 4 & 44 & 5 & 73 & 14 \\
Year 5 & 0 & 104 & 178 & 13 \\
\hline Total & 118 & & & 136 \\
\hline
\end{tabular}

Source: own research, $\mathrm{N}=536$.

\section{Research results and analysis}

The first hypothesis (H1) was tested with factor analysis performed with Varimax rotation. As a result, three factors were identified explaining $77 \%$ of the total variation. The factors correspond with the dimensions of brand community commitment proposed by Allen and Meyer (1990): affective, normative and continuance.

The statements used in the factor analysis were adapted from an existing scale used by Zhang, Zhou, Su and Zhou (2013) for an examination of brand community commitment in a computer-mediated environment. The statements were modified so that they fitted the context of higher education. 
The next step was the verification of the reliability of the scales with the use of Cronbach's Alpha. For each scale the reliability coefficient is above 0.79 which is a satisfactory result confirming good reliability of the scales (Nunnally, 1978; Churchill, Peter, 1984). Further elimination of statements would not improve the reliability of the scales. The results obtained allowed the confirmation of the first hypothesis (H1).

Table 2

Dimensions of brand community commitment and their reliability

\begin{tabular}{|l|c|c|c|c|}
\hline & \multicolumn{2}{|c|}{ Factor } & Cronbach's \\
\cline { 2 - 4 } & affective & normative & continuance & \multirow{2}{*}{0.924} \\
\hline $\begin{array}{l}\text { I have a strong sense of belonging to my } \\
\text { faculty }\end{array}$ & 0.878 & & & \\
\hline I feel connected to my faculty & 0.871 & & & \multirow{2}{*}{0.822} \\
\hline $\begin{array}{l}\text { I have a real emotional attachment to my } \\
\text { faculty }\end{array}$ & 0.864 & & & \\
\hline I am a part of the faculty community & 0.840 & & & \\
\hline $\begin{array}{l}\text { I study at my faculty because I feel pres- } \\
\text { sure that I should do so }\end{array}$ & & 0.881 & & \multirow{2}{*}{0.793} \\
\hline I come here out of sense of duty & & 0.872 & & \\
\hline $\begin{array}{l}\text { I feel forced to continua studies at this fac- } \\
\text { ulty }\end{array}$ & & 0.804 & 0.875 & \\
\hline $\begin{array}{l}\text { If I stopped studying here, it would be dif- } \\
\text { ficult for me to find a better university }\end{array}$ & & & 0.794 & \\
\hline $\begin{array}{l}\text { There are very few other universities } \\
\text { where I could find such useful content as } \\
\text { at my faculty }\end{array}$ & & & 0.702 & \\
\hline $\begin{array}{l}\text { Studying here is too valuable for me to } \\
\text { stop }\end{array}$ & & & & \\
\hline
\end{tabular}

Source: own research, $\mathrm{N}=536$.

In order to verify the second hypothesis (H2), stating that there are differences in level of student commitment among higher education institutions, Kruskall-Wallis nonparametric test was used. The results of the test are presented in table 3 and it can be observed that the differences in the level of commitment are statistically significant for the affective and continuance dimensions only and there is no significance for the normative dimension. Thus, the second hypothesis (H2) can be partially confirmed.

Table 3

Kruskall-Wallis test: commitment level at different faculties

\begin{tabular}{|l|c|c|c|}
\hline & Affective & Continuance & Normative \\
\hline Chi-square & 10.035 & 47.126 & 7.693 \\
\hline df & 3 & 3 & 3 \\
\hline Sig. & $\mathbf{0 . 0 1 8}$ & $\mathbf{0 . 0 0 0}$ & 0.053 \\
\hline
\end{tabular}

Source: own research, $\mathrm{N}=536$. 
A further look at means for each dimension and each faculty brings some interesting observations. While respondents from management and civil engineering faculties manifested rather positive attitudes in terms of the affective and continuance dimensions of the commitment, students from law and administration faculty displayed positive attitude towards continuance and negative towards the affective aspects of the commitment. In this context, respondents from the faculty of economics stand out as their attitude towards both commitment dimensions are rather negative.

Table 4

Means for commitment dimensions at different faculties

\begin{tabular}{|l|l|c|c|c|}
\hline \multicolumn{2}{|c|}{ Faculty } & Affective & Continuance & Normative \\
\hline \multirow{2}{*}{$\begin{array}{l}\text { Management } \\
\mathrm{N}=178\end{array}$} & Mean & 3.014 & 3.267 & 2.818 \\
\cline { 2 - 5 } $\begin{array}{l}\text { Law and Administration } \\
\mathrm{N}=136\end{array}$ & Std dev. & 1.003 & 0.846 & 0.970 \\
\cline { 2 - 5 } & Std dev. & 2.851 & 3.380 & 2.576 \\
\hline Economics & 1.020 & 0.916 & 1.124 \\
\hline $\mathrm{N}=118$ & Mean & 2.689 & 2.749 & 2.568 \\
\cline { 2 - 5 } $\begin{array}{l}\text { Civil Engineering } \\
\mathrm{N}=104\end{array}$ & Std dev. & 0.898 & 0.825 & 0.936 \\
\hline \multirow{2}{*}{$\begin{array}{l}\text { Total } \\
\mathrm{N}=536\end{array}$} & Mean & 3.026 & 3.494 & 2.583 \\
\cline { 2 - 5 } & Std dev. & 1.143 & 1.016 & 1.057 \\
\cline { 2 - 5 } & Mean & 2.903 & 3.226 & 2.656 \\
\hline
\end{tabular}

Source: own research, $\mathrm{N}=536$.

The third hypothesis stated that there are differences in the level of commitment between man and women. The results of Mann-Whitney $U$ test are presented in table 5 and it can be observed that there are no statistically significant differences. Therefore, the hypothesis $\mathrm{H} 3$ is rejected.

The final, fourth hypothesis stated that each of the dimensions of brand community commitment correlated with the students' loyalty towards the university. The student loyalty scale consists of four statements representing their satisfaction with the studying, repurchase intention and propensity to recommend the faculty to other people (Narayandas, 1996; Oliver, 1999). The reliability of this scale was verified with Cronbach's Alpha coefficient which exceeded 0,8 proving satisfactory scale consistency (see tab. 6).

Table 5

Mann-Whitney U test: commitment level and gender

\begin{tabular}{|l|c|c|c|}
\hline & Affective & Continuance & Normative \\
\hline Mann-Whitney U & 30686.000 & 31717.000 & 30811.500 \\
\hline Wilcoxon W & 91412.000 & 93142.000 & 48202.500 \\
\hline Z & -0.891 & -0.389 & -1.024 \\
\hline Sig. (2-tailed) & 0.373 & 0.697 & 0.306 \\
\hline
\end{tabular}

Source: own research, $\mathrm{N}=536$. 
Reliability of students' loyalty towards the university scale

\begin{tabular}{|l|c|}
\hline & Cronbach's Alpha \\
\hline I would choose the same faculty again & \\
I often tell positive things alb out my faculty to people close to me & 0.824 \\
I like studying at my faculty & \\
I gladly recommend my faculty to other people & \\
\hline
\end{tabular}

Source: own research, $\mathrm{N}=536$.

As can be seen in table 7, the correlation is statistically significant for all commitment dimensions: affective, continuance and normative. Thus, the fourth hypothesis (H4) is confirmed. The strength of the correlation varies, in case of the affective and continuance dimensions it is strong, while for the normative dimension it is moderate (Wierzbiński, 2006). It is interesting to observe that while the relationships between the affective and continuance dimensions and students' loyalty are positive, the one for the normative dimension is negative, which means that the more students feel obligated to continue their studies at a particular faculty, the less loyal they are toward the institution.

Table 7

Spearman's rho correlation coefficient for commitment dimensions and students loyalty towards the university

\begin{tabular}{|ll|c|c|c|}
\hline \multicolumn{2}{|c|}{ Spearman's rho } & Affective & Continuance & Normative \\
\hline Loyalty towards & Correlation coefficient & $0.619^{* *}$ & $0.514^{* *}$ & $-0.370^{* *}$ \\
the university & Sig. (2-tailed) & 0.000 & 0.000 & 0.000 \\
& $\mathrm{~N}$ & 533 & 535 & 536 \\
\hline
\end{tabular}

Source: own research, $\mathrm{N}=536$.

\section{Discussion}

The results of the study presented above allow for several conclusions and practical implications. First of all, the model of three-dimensional brand community commitment in higher education has been verified. It is interesting to observe that the highest level of commitment was reported for the continuance level (3.23) and the lowest for the normative one (2.66). This implies that students are aware of high sunk costs of studying at a particular faculty and at the same time do not have the sense of obligation towards the university community. What is more, the means for continuance and affective commitment dimensions differ among the faculties, thus each institution has the ability to influence students' commitment level.

Secondly, the relation of commitment dimensions with the loyalty towards the university has been positively verified. It is noteworthy that the sense of obligation to the community and its members (normative commitment) correlates 
negatively $(-0.370)$ with students' loyalty which combined with low level of this type of commitment among students presents a favourable situation for the faculties. Both continuance (0.514) and affective (0.619) commitment are positively related to students' loyalty. Given the low level of the affective commitment (2.90) among students participating in the study, it presents an opportunity for the universities which should focus on enhancing this type of commitment and thus building stronger students' loyalty.

This study is not without its limitations that result from the sampling method applied and the use of a survey technique. Therefore, it is suggested that further research is conducted on a randomly selected sample and other research techniques are used (such as observations, experiments and interviews).

\section{Bibliography}

Algesheimer, R., Dholakia, U.M., Herrmann, A. (2005). The social influence of brand community: Evidence from European car clubs. Journal of Marketing, 69 (3), 19-34.

Allen, N.J., Meyer, J.P. (1990). The measurement and antecedents of affective, continuance and normative commitment to the organization. Journal of Occupational and Organizational Psychology, 63 (1), 1-18.

Belk, R., Tumbat, G. (2005). The cult of Macintosh. Consumption, Markets, and Culture, 8 (3), 205-217.

Boorstin, D. (1973). The Americans: The Democratic Experience. New York: Random House.

Churchill, G.J., Peter, J. (1984). Research design effects on the reliability of rating scales: a metaanalysis. Journal of Marketing Research, 21 (4), 360-375.

Cova, B. (1997). Community and consumption: towards a definition of the linking value of product and services. European Journal of Marketing, 31, 297-316.

Dziewanowska, K. (2016). Wymiary przynależności do społeczności wokół marki uczelni i ich konsekwencje. Przedsiębiorczość i Zarządzanie, XVII (4), 161-176.

Firat, F., Dholakia, N. (1998). Consuming people: from political economy to theatres of consumption. London: Routledge.

Jang, H., Olfman, L., Ko, I., Koh, J., Kim, K. (2008). The influence of on-line band community characteristics on community commitment and brand loyalty. International Journal of Electronic Commerce, 12 (3), 57-80.

Kozinets, R. (2001, June). Utopian enterprise: articulation the meanings of Star Trek's culture of consumption. Journal of Consumer Research, 28, 67-88.

Martin, M.C., Moriuchi, E., Smith, R.M., Moeder, J.D., Nichols, C. (2015). The importance of university traditions and rituals in building alumni brand communities and loyalty. International Academy of Marketing Studies Journal, 19 (3), 107-118.

McAlexander, J.H., Koenig, H.F. (2010). Contextual influences: Building brand community in large and small colleges. Journal of Marketing for Higher Education, 20 (1), 69-84.

McAlexander, J.H., Koenig, H.F., Schouten, J.W. (2006). Building relationships of brand community in higher education: A strategic framework for university advancement. International Journal of Educational Advancement, 6 (2), 107-118.

McAlexander, J., Schouten, J., Koenig, H. (2002). Building brand community. Journal of Marketing, 66 (1), 38-54.

Meyer, J.P., Herscovitch, L. (2001). Commitment in the workplace: toward a general model. Human Resource Management Review, 11 (3), 299-326. 
Morgan, R.M., Hunt, S.D. (1994). The commitment-trust theory of relationship marketing. Journal of Marketing, 58 (3), 20-38.

Muniz, A., O’Guinn, T. (2001). Brand community. Journal of Consumer Research, 27 (4), 412 432.

Narayandas, N. (1996). The link between customer satisfaction and customer loyalty: an empirical investigation. Boston: Harvard Business Scholl.

Nunnally, J. (1978). Psychometric theory. New York: McGraw-Hill.

Oliver, R.L. (1999). Whence consumer loyalty? Journal of Marketing, 63, 33-44.

Schouten, J., McAlexander, J. (1995, June). Subcultures of consumption: an ethnography of the new bikers. Journal of Consumer Research, 22, 43-61.

Wierzbiński, J. (2006). Statystyka opisowa. Warszawa: Wydawnictwo Wydziału Zarządzania Uniwersytetu Warszawskiego.

Zhang, N., Zhou, Z.-m., Su, C.-t., Zhou, N. (2013). How do different types of community commitment influence brand commitment? The mediation of brand attachment. Cyberpsychology, Behavior, and Social Networking, 16 (11), 836-842.

\section{Wymiary zaangażowania w społeczność wokół marki na przykładzie szkolnictwa wyższego}

Słowa kluczowe: społeczność wokół marki, zaangażowanie, szkolnictwo wyższe

Streszczenie. W artykule skoncentrowano się na kwestiach zaangażowania w społecznościach wokół marki w szkolnictwie wyższym oraz jego związku z lojalnością studentów wobec uczelni. Artykuł składa się z dwóch części. W pierwszej przedstawiony jest przegląd literatury przedmiotu z zakresu społeczności wokół marki i zaangażowania, natomiast w części drugiej omówiono wyniki ilościowego badania własnego. Celem badania była weryfikacja trzywymiarowego modelu zaangażowania w społeczności wokół marki uniwersytetu oraz relacji wymiarów afektywnego, normatywnego i zobowiązania do kontynuacji z zachowaniami lojalnościowymi.

Translated by Katarzyna Dziewanowska

\section{Cytowanie}

Dziewanowska, K. (2017). Dimensions of brand commitment - case of higher education. Marketing i Zarządzanie, 1 (47), 173-181. DOI: 10.18276/miz.2017.47-16. 



\section{Jacek Dziwulski}

\section{Kreowanie wizerunku organizacji na przykładzie Spółdzielni Pszczelarskiej „Apis” w Lublinie}

Kody JEL: M00, M3

Słowa kluczowe: kreowanie wizerunku, wewnętrzny wizerunek organizacji, zewnętrzny wizerunek organizacji

Streszczenie. W artykule przedstawiono istotę tworzenia i budowania wizerunku organizacji, zarówno w wymiarze wewnętrznym, jak i zewnętrznym. Poddano w nim analizie i ocenie wybrane elementy wizerunku zewnętrznego Spółdzielni Pszczelarskiej „Apis” w Lublinie. W podsumowaniu zwrócono uwagę na ważność wybranych elementów budowania wizerunku organizacji na wybranym przykładzie. Zaproponowano rekomendacje do realizacji w przyszłości.

\section{Wprowadzenie}

Właściwa budowa wizerunku organizacji i odpowiednie zarządzanie nim nie jest prostym zadaniem. Odpowiedzialność z tym związana powinna spoczywać na zarządzie przedsiębiorstwa. Wymaga jasno określonych celów, wizji, czasu, profesjonalizmu oraz środków finansowych.

W artykule wskazano istotne elementy zarządzania wizerunkiem organizacji jako ważnego elementu promocji przedsiębiorstwa oraz skuteczności prowadzonych przez niego działań. Przyjęto tezę artykułu, że kreowanie pozytywnego wizerunku organizacji zarówno wewnątrz niej, jak i w jej otoczeniu zewnętrz- 